\title{
Europa som ekstrem
}

\section{Guds død i det kristne Europa og i Islam}

\author{
Abdelwahab Meddeb
}

I

Ikke-europæeren kan ikke komme uden om Europa som spørgsmål. Uanset om han faktisk forflytter sig dertil eller om han forbliver på sit eget kontinent, konfronteres han med Europa både som begreb og i form af dets konkrete manifestation, der er synligt overalt på jorden i teknikkens verdensomspændende udtryk. Dette universelle udtryk kan måske ses som en sidste manifestation af Ånden.

Jeg vil ikke her forfølge dette spor, men blot minde om, at ikke-europæeren stillet over for denne universalitet konfronteres med spørgsmålet om sin egen rolle i fremstillingen af teknologiens objekt. Svaret på dette spørgsmål afhænger naturligvis af, i hvilken udstrækning man selv behersker de færdigheder, som den skabende proces forudsætter.

Jeg mener dog ikke, brugen af dette objekt nødvendigvis forudsætter delagtighed i skabelsen heraf. Enhver menneskelig opfindelse, uanset oprindelse, tilhører menneskene; og alle har en umistelig ret til at nyde godt af, hvad den fører med sig. Det er på den måde, at den samlede mængde af opdagelser og viden har kunnet cirkulere mellem alle nationer, folkeslag, sprog og civilisationer. I.historiens løb har bidrag fra snart den ene snart den anden part overskredet de grænser og identiteter, der adskiller og skaber splid. På trods af alle ødelæggende og blodige konflikter, trods krige og udryddelsesforsøg, har det altid været muligt at finde tilbage til den ideelle tilstand i en enestående diakroni, 
hvor alle menneskelige opfindelser konvergerer og bliver universelle.

Det gælder os alle, at vi overhales af den aktuelle teknologiske udvikling (der går så vidt som til computersimulation af den meneskelige intelligens); ingen kan længere vurdere konsekvenserne. Og opretholdelsen af den fælles diakroni kræver mere end nogensinde før en heroisk viljesanstrengelse. Hvis ikke opmærksomheden om emnet skærpes, vil dets kompleksitet, den hastighed hvormed det forandres, umuliggøre at alle får del i vidensoverførslen. Det er dog lykkedes for nytilkomne at gennembryde de tilsyneladende vandtætte forhindringer. Og det er ikke umuligt at forestille sig, at vi i vores samtid vil komme til at opleve en forskydning, af det Fernand Braudel kalder verdenshovedstaden, $\mathrm{i}$ retning af Stillehavet og den asiatiske verden.

I virkeligheden gør systemets kompleksitet det ikke utilgængeligt. Tværtimod bliver adgangen til viden, uanset hvor vanskelig den forekommer, umulig at kontrollere for dem der gerne fortsat vil være alene om at drage fordel af den. Men man må dog give afkald på mange nedarvede traditioner og fordomme for at opnå del, om ikke i systemet selv så dog i en mod-magt, i en modstand som kan true magten.

Indtil da vil ens forventninger til fremtiden være afhængig af, om man er delagtig i skabelsen af en ting, eller om man stiller sig tilfreds med at være bruger og forbruger af den. Denne forskel vækker en psykologisk usikkerhed, hos dem der ikke er delagtige, og truer deres æresfølelse; nogle forsumper i følelser af nag, mens det hos andre vækker en selvfølelse, der leder dem til at tro, at deres manglende indflydelse er noget forbigående. De bruger således hele deres energi på at få greb om noget, der unddrager sig dem, for at tilegne sig det og bruge det til deres egne formål.

Udfordringen består $\mathrm{i}$ virkeligheden $\mathrm{i}$ at tilegne sig den herskerviden, der ligger til grund for det europæiske overherredømme. Dog uden at give køb på egne traditioner, men således at denne viden indarbejdes, så man kan genfinde sit eget oprindelige sprog. Et sprog der vil se sig fornyet ved denne frugtbare omformning eller gendigtning (oversættelsens ypperste stadium), hvilket også medfører en grundlæggende forvandling af 
nedarvede værdier. Disse vil så forlade bogstavets svøb for at blive til levende spor, hvoraf der kan udvindes et middel til at læge de skrammer, der uundgåeligt vil tilfalde den, der indlader sig på et sådant eventyr.

\section{II}

Som et menneske med rod i Islam vil jeg gøre opmærksom på det, der slog mig mest i mødet med Europa, hvor jeg selv oplevede den fremmedes prøvelser. Men jeg vil først, uden dog at opholde mig længere tid derved, påpege en række indsigter af afgørende historisk betydning, der opnåedes i oplysningstiden. $\mathrm{Og}$ så inden jeg går videre, give udtryk for en beklagelse.

De nævnte indsigter har baggrund i adskillelsen af det politiske og det religiøse, hvilket indfører et juridisk og moralsk referencepunkt, hvis transcendens ikke længere er henvist til en guddommelig oprindelse for loven. Men selve tanken om denne adskillelse (der efter en århundreder lang proces resulterede $\mathrm{i}$ den virkelige adskillelse) findes første gang i en tekst, der er skrevet på arabisk og modnet i den islamiske tænknings smeltedigel. Fornuftens ufravigelige fordring, der også krævede sin ret inden for den teocentriske lærebygning, formuleredes af Averroès (død i 1198), og det var her hans vestlige og kristne efterfølgere tog udgangspunkt, når de metodisk hævdede begge områders autonomi gennem læren om "den dobbelte sandhed": dogmet og den filosofiske spekulation.

Min beklagelse gælder det svigt, der har gjort, at Averroès er uden efterfølgere inden for arabisk og islamisk tænkning. Svigt er et svagt ord. Det er ingen overdrivelse at tale om tankemæssig sterilitet, genealogisk brud. Den dag i dag kæmper Islam fortsat med problemer, hvis løsning man ser ansatserne til allerede hos Averroès, dvs. i det 12. århundrede.

I Europa derimod har den averroèistiske tradition været ubrudt, og et århundrede efter kommentatoren fra Cordobas død foreslog Dante løsninger på to problemer, der stadig vejer med hele deres tyngde på den arabiske nutid, i en grad så man kunne 
forledes til at se dem som to uforanderlige karaktertræk, der på ulykkelig vis kendetegner Islam.

Det drejer sig på den ene side om teoretiseringen af det komplicerede forhold mellem den gejstlige og den verdslige magt, mellem pave og kejser i deres egenskab af to differentierede enheder skønt forbundet af et netværk af relationer, til hvis definition man må tage logikken til hjælp: det bestræber Dante sig på i sin' afhandling om monarkiet (De monarchia libri tres).

Det drejer sig på den anden side om at give folkesproget udtrykskraft, litterært niveau, idet man skaber et værk næret af den dybeste tænkning, der om ikke ophæver den opspaltning som den litterære repræsentation indebærer, så dog formindsker den uundgåelige afstand så meget som muligt. Ud over den teoretiske behandling i De Vulgari Eloquentia (Om folkesprogets udtrykskraft) ses et praktisk eksempel på løsningen af problemet $\mathrm{i}$ brugen af det toskanske sprog i Den Guddommelige Komedies triptykon.

I modsætning hertil er Islam blevet hængende $\mathrm{i}$ enheden af politik og religion; endnu har den arabiske verden ikke kunnet lø̣srive sig fra en dimension af det hellige, der får dens sprog til at stivne og skaber illusionen om, at forbindelsen til oprindelsesscenen aldrig er blevet kappet. Når et sprog er bestemt af en metafysisk vision, er det vanskeligt at forhindre et uheldssvangert udviklingsforløb med retning mod katastrofe eller entropi; det kan tyskerne tale med om.

Hjemkommen efter de prøvelser i fremmedhed han har mødt under europarejsen, genfinder den arabiske digter disse to grundlæggende temaer, uberørte siden århundreder. Han genfinder dem i en kontekst af politisk vold, som han må konfrontere for at bringe disse ting på tale, og med risiko for sit eget liv. Identitetstænkningen og dens uundgåelige følgeslutning: afvisning af Vestens eksempel, har i den grad fået følelserne af indre modstand til at slå om $\mathrm{i}$ blind rasen. 


\section{III}

Opdagelsen af en vigtig fase i den europæiske udvikling indgav mig imidlertid trøst og forsonede mig med min islamiske herkomst. Jeg tænker her på den fase, der vedrører genopdagelsen af den hedenske krop og dens forening med den åndens suverænitet, der har hersket siden Europa tilegnede sig fundamentet for jødedommen (den åbenbarede Bog).

Mens denne generobring af kroppen skete meget tidligt i Italien ved at gribe tilbage til hedenske myter i maleri og digtekunst, og mens det i Frankrig skete via materialismen (jeg tænker navnlig på Diderot), former denne genopdagelse sig anderledes i Tyskland. Her genopdages kroppen nærmest gennem fascination og imitation af et orientalsk forbillede.

Således Goethe, som begejstres af sensualismen i den arabiske og persiske lyrik, der næsten panteistisk besynger Guds immanens, tolker naturfænomenerne som en åbenbaringsvision og omfatter alle ting med kultisk andagt.

Man kan også konstatere, at genopdagelsen af netop denne Orient lå helt på linie med en bestemt Spinoza-reception formuleret af bl.a. Heine, der i øvrigt havde en svaghed for Andalusiens magi: Dette kan aflæses af de mange detaljer her fra, som indgår i det væv af citater og reminiscenser, der er karakteristisk for dybden af hans lærdhed: Låner han ikke Muhammeds udtryk "Bogens folk" for at betegne jøderne som indstiftere af Ånden? Denne reference bruger Heine på det tidspunkt i Zur Geschichte der Religion und Philosophie in Deutschland, hvor han påkalder sig kroppens ret som ligeværdig med åndens suverænitet, som, ifølge Hegel, skyldes Bibelen.

Denne reference til Muhammed er ikke tilfældig, eftersom man ved, at i de tre kulturers Spanien, i striden mellem de tre monoteismer, gælder den kropslige nydelse som det, der udmærker muslimen i forhold til de andre, som det hedder i Libre del gentil e los tres savis af Raimundus Lullus. Og i Libro della scala, en anonym fortælling om profeten for Islams opstigning til himmels, der på initiativ af Alphonse le Sage blev oversat fra arabisk i Sevilla i det 13. århundrede, er Muhammeds samfund privilegeret 
ved retten til i fuld legitimitet at nyde denne verdens goder, der ophøjes til udtryk for en guddommelig nåde.

Også Nietzsche stiller den kristne nihilismes fornægtelse af nydelsen op som modsætning til muslimernes kropskult; og som illustration af denne modsætning bruger han en anden andalusisk anekdote, om den første forordning som de kristne myndigheder satte i værk efter generobringen af Cordoba. Den bestod i at lukke byens syv hundrede hammam'er, som man opfattede som utugtige og skændige steder, der uvilkårligt opfordrede til kropskontakt.

Hvad er i øvrigt disse hammam er andet end en adaption af de romerske bade? De er således spor i arkitekturen, vidnesbyrd om at også Islam var åben over for kroppens glæder, ærede kroppen. Et tegn på at monoteisten ikke længere tog afstand fra den hedenske arv, men - ved siden af det absolutte, uendeligheden og evigheden i det guddommelige budskab, også indtænkte menneskekroppens forgængelighed. Det er ikke overflødigt at insistere på dette grundlæggende træk i Islam, der viser, at Islams forhold til det mediterrane snarere er kendetegnet af kontinuitet end af brud (for at genoptage det sæt af modsætninger som Henri Pirenne bruger i sin Mahomet et Charlemagne). At denne overtagelse af en romersk tradition skyldtes en hygiejnisk forskrift om at rense sig efter den seksuelle akt, tager ikke glansen af denne latin-islamiske kontinuitet. Tværtimod, ceremonien omgiver kroppen med en forklarelsens stråleglans netop på grund af den forudgående nydelse, som en religiøs transfiguration der gør den modtagelig for epifanien.

Faktisk er Islam, der ikke kender til arvesynden og syndefaldet, strukturelt bedre egnet til at videreføre hedenske samfundstraditioner end kristendommen. Så hvilken historiens ironi er det, der i dag gør Islam så snerpet overblufærdig, med en kvælende moralkode der gennemtvinger adskillelsen af kønnene og kvindernes tilsløring, på et tidspunkt hvor Europa oplever en frisættelse og en iscenesættelse af den nøgne krop, som en virkeliggørelse af løftet om et nydelsens paradis her og nu på jorden?

De ulyksalige efterretninger, der når os fra de islamiske lande, fratog mig den trøst, der i begyndelsen af mit ophold i Europa 
forsonede mig med min islamiske herkomst. Man burde minde Islams nye Tartuffe'r, der fægter om sig med fordrejede eller forældede skrifter og proklamerer sig selv som forsvarere af deres renhed, om at dogmet absolut ikke udelukker nydelsen. Tror de virkelig, de kan få stillet deres hævnlyst ved at overtage magten i byer som de dernæst lader forbløde af en terror, der fornægter kroppen uden derfor at vinde nogen form for åndelighed? Skulle de nogensinde opnå at triumfere, ville de se sig konfonteret af ruiner og intethed.

\section{IV}

Jeg vender tilbage til Europa, som er emnet for denne artikel. Hvad jeg hidtil har sagt om Europa, drejede sig om de almene forudsætninger, der lagde vejene åbne for mine strejftog og ikke udelukkede kortere eller længere ophold. Det blev en lang vandring på dette kontinent, af og til med forhindringer men altid betagende. Den lære, jeg uddrager deraf, ligger i forlængelse af en ide formuleret af Paul Valéry i Regards sur le monde actuel: Europa stræber frem for alt og på alle områder efter det maksimale (med hensyn til arbejde, behov og tilfredsstillelse, kapital, udbytte, ambition, magt, handel, kommunikation osv). Selvsamme Europa har drevet alt, hvad det har foretaget sig, til grænsen, til det ekstreme. Europa kender ikke til det at slå sig til tåls, hverken når det drejer sig om det gode, om det onde, om opbygning eller nedbrydning, civilisation eller barbari. ${ }^{1}$ Det er denne ubønhørlige ufravigelighed, der skræmmer og fascinerer. Den er på en gang sejrrig og umenneskelig.

Jeg vil ikke her forfølge og dømme om denne ambivalens, for det er på en gang problematisk at være dommer og gæst. Det gælder om at finde udveje for at omgå risikoen for loyalitetsbrud eller forræderi. Det jeg søger er at forstå og at placere mig i denne stejle topografi, jeg spekulerer ikke på at jævne ud eller finde kompromisser. Jeg ved, at rejsen er uden ende, men det betyder ikke, at jeg er en rodløs outsider, landsforvist og på flugt, som kæmper for at komme frem uden at komme ud af stedet. Det betyder blot, at denne søgen er uendelig, mens opholdet altid vil 
være temporært, en udsættelse. Bevægelsen er selve livet, hvilen er ikke af denne verden.

Det synes, som om det er jeg-kultens opkomst, der er kilden til denne europæiske ekstremisme. Formuleringerne af denne kult er naturligvis varierede og nuanceres fra Montaigne til Rousseau, fra Descartes til Kant, med hensyn til såvel begreber som mål og indsats. Men alle: strenge rationalister, impulsive tilhængere af den umiddelbare nedskrift, rigoristiske systemkonstruktører, fragmentets eller aforismens partisaner, skeptikere eller epikuræere, følelsernes entomologer eller sansningens fysiologer, abstraktionens eller metaforens mestre, de vanvittige på studerekamrene eller de livsdyrkende hedonister, filosoffer eller digtere, bofaste eller rejsende - alle forenes de $i$ indsættelsen af jeg'et som samlende figur.

Via antropocentrismen, der afløste teocentrismen, triumferede altså et subjekt, hvis suverænitet forblev upåvirkelig på trods af de ødelæggelser, angreb og krænkelser, som senere skulle sprænge det selvbehagelige billede, det havde skabt af sig selv, og kun efterlade spredte vragrester flydende som rene overfladefænomener af moral og psykologi. I kølvandet på de franske moralister i det 18. århundrede, efter Nietzsche og Freud, er det blevet latterligt at ville camouflere egoisme som altruisme, selvkærlighed som næstekærlighed, dragningen til død og ødelæggelse som en besværgelse af det gode. Fra da af gælder det om at se det onde i øjnene. Identitetens sygdomstilstand bliver mere og mere påtrængende og udbredes stadig hurtigere, og rammer såvel enkeltindivider som hele folkeslag og nationer. Aldrig tidligere har en kultur set sig konfronteret med de altødelæggende konsekvenser af et sådant klarsyn, et sådan ophør af fortryllelse.

Men disse afsløringer afbryder kun kortvarigt subjektets magt og centrale stilling; delt, splittet, decentreret, ikke længere fuldt herre over sin bevidsthed eller sproget, rekonstituerer subjektet sig i den position, det har indtaget siden Descartes: Som en Føniks der genopstår af asken. Alt i alt har alle destruktionsforsøg, tvært imod at svække subjektet, styrket det. Det er gennem opretholdelsen af dette djævelske spil (der minder om en 
ondskabsfuld spøg), at Vestens triumfatoriske herredømme som institution kan fortsætte, takket være et subjekt der teoretisk set er medtaget men i praksis intakt. Den konstante kritik styrker i længden dets immunitet.

Også kunstarterne vidner om dette fundamentale paradoks, hvor jeg-kult findes side om side med destruktion som æstetisk princip. Ikke alene bliver der malet flere og flere selvportrætter, der efterhånden udgør en egen genre, men mange af de store mestre forekommer at være besat heraf, så de næppe kan male andet end deres eget billede, der bliver til en slags arketype, som enhver anden figur, virkelig, fiktiv, allegorisk eller mytisk, må tage form efter.

I øvrigt følger og fortrænger stilarterne og metoderne hinanden nådesløst. Nedbrydningen af koderne sker med samme entusiasme som etableringen af dem. Og det gælder ikke kun for de uundgåelige manieristiske eller barokke faser, der følger efter klassiske epoker. Nedbrydningen er heller ikke blot vort århundredes kendetegn, selvom den åbenlyst er blevet et mål i sig selv, i en grad så den kreative energi bortødsles og udtømmes og ender i ingenting. Det æstetiske princip, der truer og tilintetgør koden, har allerede længe øvet denne undergravende virkning. Det viser sig hos stærke personligheder, der insisterer på hidtil ukendte billedverdener og arbejder på at finde et nyt billedsprog for at holde kunsten levende.

Som illustration vil det være fuldt tilstrækkeligt at minde om tre store spanske malere: El Greco for det religiøse sujet og en vision af det mystiske; Velasquez for sine hofscenarier og politiske parader, undertiden fordoblede gennem refleksioner over det at male; Goya for spørgsmålet om det onde og om racens moralske og legemlige degeneration. De udfordrer inden for hver deres område en stor maletradition og udvikler en ekstrem og overdreven manér, der kan sidestilles med et ideolekt og som er udtryk for en idiosynkrasi. Stil og signatur er et og løsriver sig ikke fra det spejlbillede, der som et symptom med sin uendelige tilbagevenden måske er bestemt til at bortmane en angst eller at fremmane en frihed. 
V

Jeg er hermed fremme ved den formulering, der ikke blot er en videreførelse, af hvad der allerede er sagt, men også et emblem for det. Zarathustras skrig: "Gud er død“ genlød for mig som en uhørt og dog ventet forkyndelse. Jeg modtog denne radikale og utvetydige udtalelse som en gave fra det utæmmelige Europa, der ikke viger tilbage for noget. Jeg var prædisponeret for at høre dette,skrig, i den grad ønskede jeg at opleve Guds fravær, Gud som mangel, efter altid at være blevet oversvømmet af hans tomme fylde. Jeg lod den indre tomhed vokse i mig og begyndte at ane virkningerne af fraværets strategi. Jeg ville gøre en ende på den komedie, som affødtes af paradokset om en usynlig gud, hvis afbildning var bandlyst af billedforbudet, men som ikke desto mindre til stadighed manifesterede sig antropomorft og mødte mig praktisk taget i hver eneste sætning, i hver gestus, i hver blindgyde eller omvej i medinaen i Tunis, hvis labyrint jeg gennemkrydsede hver dag på vej til filosofiundervisningen i mit sidste år på gymnasiet

Jeg mistroede denne påtrængende nærværelse, der ikke formåede at forhindre den åbenbare formørkelse af ånden, der med katastrofale følger hjemsøgte hele det islamiske territorium ved afslutningen af kolonitidens lange nat. For mig var det kun en forførerisk illusion bestemt til at undertrykke viljen, følelsen for det tragiske og det negatives arbejde, der dog er forudsætningen for menneskets kampgejst. For hvis man tror, at alt hvad der står over én selv er det guddommeligt absolutte, undgår man ikke at blive dets slave.

Under min læsning tilbagelage jeg lidt efter lidt i modsat retning det udviklingsforløb, der førte til Guds død, en uafvendelig konsekvens da mennesket og fornuften blev sat i centrum. Det er Kant, denne omstyrter som Heine kalder tænkningens Robespierre, der konstaterer, at det efter Copernicus er blevet umuligt at forstå Gud ud fra fornuften. Og jeg forstår Nietzsches vrede mod Kant, der i medfølelse med menneskeslægten genindfører den Gud, han selv havde styrtet. Alternativet ville være at bevare stedet for det guddommelige som sted, uanset om Gud var død, 
dræbt af menneskene. Det gjaldt om at friholde pladsen efter den døde Gud og forsøge at tænke det guddommelige på en anden måde, for at holde feltet åbent for det usynlige, det usigelige og detuhørte, ikke alene tilære for digtning og metafysik men også for politik og videnskab.

Dette perspektiv på tingene giver form til en moderne faderløshed, der første gang kommer til udtryk hos Hölderlin, og hvis sene ekko i det franske sprog jeg hører hos Bataille eller Artaud. Da jeg i slutningen af tresserne kom til Paris for at afslutte mine studier, var det netop denne problematik og disse forfattere, der prægede den aktuelle debat, som reaktion på at spørgsmålet om det hellige og det guddommelige var blevet elimineret af tidligere generationers reduktionistiske materialisme. I disse år var Nietzsche populær blandt de unge; og Deleuzes lille bog helliget Nietzsche introducerede til læsningen af ham, med en vejledning der satte læseren i stand til at undgå misforståede tolkninger, der ville reducere teksten til en afskyelig samling af misogyne, racistiske, antisemistiske og nazistiske udtalelser.

Under min genopdagelse af sufismen ledte jeg så efter spor, der i det mindste kunne siges at have indvarslet den sorg og den faderløshed, som tabet af Gud medfører. Jeg forfulgte vidnesbyrd om uforfærdetheden i de ekstreme erfaringer, der udmærker den åndelige tradtion, der sætter sig op mod Koranens bogstav. Hallaj (død i 922) udråbte sig selv som Gud. Han blev henrettet. Kan man i denne død se en iscenesættelse af Guds død udspille sig i Bagdad, ubemærket af den islamiske bevidsthed?

Undertiden viser Guds umådelige nærværelse sig at være intet andet end en overlevelsesstrategi, for et subjekt der er truet og i mangel af en andethed. Det er i det mindste sådan jeg forstår f.eks. Niffaris grænseerfaring (midten af det 10. århundrede), han der som udslag af en ekstrem masochisme afstår fra talens brug for af denne skal være forbeholdt Gud, og for til stadighed i sig at holde en ustillelig, uafbrudt spørgen levende, hvilket bliver til en raison d'être i sig selv. Denne spørgens vedholdenhed og svarenes foruroligende aspekt af flygtighed får verden til at vakle, og gør det svært at etablere et fast forankringspunkt noget sted. 
Hvad skal man stille op med en Gud, som subjektet har overladt ordet for at få ham til at sige: „Bogstavet er ikke i stand til at løse sin egen gåde, hvordan skulle det så kunne løse min?" eller "mellem ordet og tavsheden hæver sig et smalt stykke land, hvor fornuften og tingene er begravet"? Denne søgen efter det usigelige $i$ en verden hvor intetheden hersker, opfinder sig et eget sprog og sin egen scene, idet den støtter sig til et faderløst bogstav afskåret fra sin kontekst i Koranen. Det jeg opdagede var altså, at netop den digteriske erfaring som noget grundlæggende rummede ødelæggelsens princip, sådan som jeg senere mange gange er stødt på det i vestlig kultur, hvor det senere igen skulle blive højst levende.

Men det er nok i sufismen, i skikkelse af Bistami (død i 847), ${ }^{2}$ jeg finder den figur, der først indvarsler den moderne faderløshed. Denne iranske mystiker, muslim af anden generation, danner forbindelsesleddet mellem den Zarathustra der var profet og reformerede den persiske religion, og den Zarathustra som Nietzsche genopfandt for at gøre ham til helt i den digteriske og filosofiske fiktion, i en æra hvor Gud afsættes og det guddommelige genopstår af ruinerne. Der er ingen tvivl om, at det er den samme scene, vi ser udspille sig, hvad enten vi bereder os på at lytte til den persiske profets dialoger med sin Gud eller til den iranske sufis ekstatiske udbrud eller den tyske filosofs dityramber. Et ekko af ærefuld og heroisk bekræftelse genlyder mellem de tre diskurser.

Det jeg fæstner mig ved hos Bistami, er hans bespottende omgang med altings Enhed: denne insisteren på jeg'ets ubrydelige kerne i en forenings- og tilintetgørelseskultur, denne konstatering af troens selvbedrag, det stædige forsøg på at befri sig for det onde og udviske den skyld hvormed subjektet skulle tilpasses den Andens lovmæssighed, denne selvbevidste stolthed der vil friholde moralen fra straf og belønning, den ironi subjektet udøver i sine intime samtaler med en Gud, hvis realitet fortaber sig alene på grund af et spil med pronominer. For hvad er der tilbage af Gud, når sufi'en får Ham til at omtale sig selv som fraværende, i tredje person, - vel vidende at tredje persons prono- 
men på en gang er Enhver og Ingen, og altså kan betegne enhver fraværende, men ikke en tilstedeværende samtalepartner. ${ }^{3}$

Ud over i sufismen og i religiøse forfatteres digtning og spekulative tekster har jeg kunnet følge idéen hos Motaziliterne. Disse rationalistiske teologer fra det 9. århundrede førte i Bagdad en voldelig kampagne mod den bogstavtro ortodoksi; de fratog Gud alle attributter, fjernede al antropomorfisme, gjorde Ham utilgængelig, forviste Ham til abstraktionens eksil.4 Denne distance, denne adskillelse fra verden var så godt som en forsvinden, der naturligvis fik følger for menneskers frihed og ansvarlighed, ligesom det naturligvis var et angreb på dogmet om Koranens ord som det evige og ikke-skabte. Det er helt sikkert, at en sådan Guds forskansning i et hinsides, uigennemtrængelig for det menneskelige, bereder én på uden undren eller traumer at acceptere denne Guds forsvinden om ikke Hans død.

\section{VI}

Langt senere stod det åbenlyse endelig lige så klart for mig som dette bord, hvor jeg her til morgen har spist morgenmad i sommersolens klare lys. Når man er vokset op i den kristne tro, er det at erklære Gud for død ikke andet end at tage dogmet på ordet, fange det i bogstavelighedens fælde. Kritikken, hvem intet er helligt, giver således den religiøse fiktion sin velsignelse og underminerer den indefra. Og i den europæiske kunst finder man mange vidnesbyrd om denne Guds død, som dogmet forkynder. Igennem århundreder har den vedholdende affødt meget virkningsfulde fremstillinger inden for alle områder af kunsten. Jeg vil her nævne to eksempler fra malerkunsten, der adskiller sig meget fra hinanden med hensyn til epoke, stil og betydning.

Som det første Korsfæstelsen af Giotto, en freske malet i kapellet $\mathrm{i}$ arenaen i Padua, Capella degli Scrovegni (omkring 13041306). Den rustfarvede, forladte kjortel ses mellem hænderne på to soldater i færd med at diskutere med en gruppe personer til venstre i billedet. Den faldne kjortel, der ikke længere formes af kroppens fylde men har genfundet klædets blødhed, udstillet i al sin tomhed, oprejst med gabende halsåbning som en halshugget 
ham, denne kjortel signalerer på en intens måde Guds afklædte krop, hvis jordiske ophold er til ende. Uimodståeligt ledes blikket mod centrum af fresken til korset med den døende, den forsvundne krop uden sin kjortèl. Således kommer budskabet om Guds død dobbelt til udtryk: i selve korsfæstelsen og i den tomme kjortel, Guds jordiske klædning. Kjortelen uden indhold udtrykker endog Guds død og forsvinden bedre end kroppen, der lider på korset og ser ud til ikke længere at tilhøre denne verden, i den grad drager hans formørkede ansigtstræk ham ud i en fjern dunkelhed.

Det der gør, at jeg føler en særlig forbundethed med dette billede (ud over at det tilhører en vigtig billedcyklus af en maler, med hvem den glorværdige diakroni i europæisk malerkunst tager sin begyndelse), er tilstedeværelsen af forgyldte arabiske bogstaver dels på den nu tomme kjortels borter, dels på de to lodrette bånd på det gennemskinnelige lændeklæde, der dækker den korsfæstede Søns køn. Jeg ville ikke have fremdraget dette, hvis der kun havde været tale om endnu en pseudo-kalligrafi, som det ofte ses på malerier fra Trecento, for at angive at de luksuriøse stoffer, der pryder de hellige personer, er importeret fra Orienten. Men efter at have tydet disse bogstaver, lød der for mig - midt i den kristne ihukommelse af Kristi død, et ekko af den islamiske trosbekendelse: „Der er ingen Gud uden Allah, og Muhammed er hans profet".

Også i andre værker inden for den kristne kunst er historikere stødt på det islamiske credo, shahada, som jeg lige har citeret; bl.a. smykker det hovedbeklædningen på en katalansk jomfru Maria. ${ }^{5}$ Men på Kortfæstelsen af Giotto kommer shahada'en til udtryk på en bemærkelsesværdig måde; alle dens ord, bogstaver og stavelser står skrevet, men uden orden; som et halvt hemineligt rygte, hvoraf man kun har opfanget brudstykker, eller som om teksten var dikteret af en stammer, en ordblind eller en ikke-arabisk katekumen, der er ved at lære Islams grundsætninger på originalsproget. Denne manglende orden skyldes sandsynligvis bare ubehændighed eller ligegyldighed hos en maler, der uden at studere skrifttegnene særlig grundigt kopierer et sprog han ikke kender. 
Som forklaring på den anomali, som det islamiske credos indtrængen i Maria- og Kristusscenerne udgør, argumenterer historikerne for, at de europæiske håndværkere og kunstnere ikke kendte det arabiske sprog, men kopierede Koranens alfabet uden at forstå betydningen af det, idet de opfattede det som ornamentale motiver. Men en sådan konstatering leder blot til en truisme, der intet forklarer men tværtimod afskærer en tolkning. Er det ikke at gå for let hen over det ubevidstes aspekt? Det at forveksle et bogstav med et ornament er ikke en ubevidst handling uden konsekvenser. Sådanne bogstaver, selv i deres manglende orden, bibeholder en betydning, for den der endnu kan dechifrere dem og som før eller senere vil støde på dem og dechifrere dem, om så først flere århundreder efter nedskrivningen.

Hvorom alting er læser jeg denne ubevidste anomali som et dobbelt symptom. På den ene side har den almene vareudveksling mellem kulturerne udviklet sig til en så stærk magtfaktor og har fremprovokeret en situation, hvor Islam bliver tvunget til at deltage i den mest oprørende scene: Guds død. På den anden side opfattes bogstavet, der er fanget i det kristne dogmes kardinalbillede, ikke på en sådan måde, at muslimens polemiske udsagn erkendes fuldt ud, af den betragter det er tiltænkt. Udsagnet fastslår den unitariske sandhed og fordømmer gennem negationens retorik alt, hvad der peger hen imod Inkarnationen og den Hellige Treenighed. Billedet ville helt sikkert virke stødende for en muslim; og det tilfangetagne bogstav forbliver uforklarligt for den kristne bedende. Denne provokation kan dog ikke være blevet de berørte parter bevidst, for det ville for både den kristne og muslimen have været at anerkende en latent mareridtsforestilling, og en person med kendskab til begge trosretninger ville ikke kunne undgå at se den.

Det skulle først blive i sækulariseringens og europæiseringens tidsalder, at en person med en islamisk kulturbaggrund men forelsket i kristendommens billedkunst, en person der havde ladet sig føre med af folkevandringen fra syd til nord, skulle stå foran Giottos billede Korsfæstelsen og pludselig genkende stavelser fra shahada'en, fragmenteret og uden orden som en gennem århun- 
dreder upåagtet list fra det ubevidstes side, som ærkefjenderne den kristne og muslimen begge har været ofre for.

Eftersom to benægtelser virker samtidigt i billedet, muslimens over for den kristne og omvendt, er det oplagt at analysere det endnu en gang ud fra Freuds begreber om drømmetydningen. Den islamiske trosbekendelse deformeres under sin forskydning på den kristne scene, eller rettere sagt dets fonemer blandes sammen, bringes i uorden. Dette muliggør en fortætning af elementer fra de to fuldstændig heterogene repræsentationssystemer; og denne komplekse forbundethed skjuler en latent betydning, der fordobler den manifeste betydning. Denne overdetermination bliver tydelig, når man udskiller de lydlige elementer fra det arabiske sprog og genkender shahada'en. Derved opdager man en dobbelt profanation: på den ene side bærer den døende Kristus som en uudslettelig plet de ord, der med deres radikale påmindelse om Enheden implicit fratager ham enhver form for guddommelighed; på den anden side afsløres en naivitet i den islamiske trosbekendelse, på baggrund af den scene hvori den her fremtræder. Læst på denne måde bliver Giottos maleri Korsfæstelsen ubærligt både for den kristne og for muslimen. Det rummer et potentielt mareridt, hvor fjendens banner rykker stadig nærmere og til sidst trænger ind af de inderste lag i ens identitetsfølelse, et mareridt der kan få én til at tænke på den politik, der til hver en tid har ledsaget kriser og foranderlige magtforhold, og hvis reaktioner har svinget mellem ekstremer som omvendelse og fordrivelse, forsvinden og udryddelse.

Og nu til det andet eksempel der skal illustrere, i hvilken grad Vesten var forberedt på tanken om Guds død, et meget sigende eksempel for det der er mit ærinde her. Dette værk skal findes i den nordlige del af Europa og to århundreder senere end Giottos freske: det er Korsfæstelsen fra den berømte altertavle udført omkring 1515 af den frankiske maler Matthias Grünewald for Antoniusstiftelsen i Isenheim, og hvis rester nu befinder sig i Colmar tyve kilometer derfra, $i$ et tidligere kapel omdannet til museum $i$ dominikanerklosteret Unterlinden. Korsfæstelsen illustrerer så absolut og betingelsesløst Guds lidelse og død, at det overskrider alle realistiske eller idealiserende traditioner inden for maleriet. 
Denne enestående maler driver sin realisation af tanken om Guds død til grænsen for det udholdelige. "Le coma du Christ de Colmar" som Huysmanns kalder det, konfronterer betragteren med det ubærlige. Det viser en kvæstet krop dækket af torne og splinter, fuld af væskende flænger og dybe sår, små kratere i huden der ser ud til at bløde kun for at fremskynde det grønlige og gustne køds forrådnelse og altomfattende infektion og dermed intensivere billedets udtryk af smerte, gøre den mere absolut, ligesom Kristi forvrængede ansigtstræk hvor de hængende læber viser dødskampens forladthed. Denne overdrevne fremhævelse af det dyriske degraderer den guddommelige, til det yderste en menneskekrop kan udholde; Huysmanns siger: „Gudemennesket fra Colmar er nu ikke andet end en ussel røver, som man har tilredt på det skændigste".

Den samme maler har malet andre lignende, lige så voldsomme scener med den døende Kristus, som om han ville åbenbare for de mest syge troende, dem der led af den mest uudholdelige dødsangst (måtte deres kroppe end plages af jagende smerter fra tusinde inficerede brandbylder), at ingen anden end Han kunne lide så meget. Lad mig endnu en gang citere Huysmanns, der i Là-bas (1891) kommenterer et andet værk af Grünewald (Korsfæstelsen fra Tauberbischofsheimer alteret, som han så i Kassel, og som nu findes i Karlsruhe):

Aldrig nogensinde har en maler på den måde rodet rundt i det guddommelige benhus og så brutalt dyppet sin pensel i kropsvæskernes kar og i sårenes blodige bægre [...] en Gud fra lighuset [...] Guds udspilede kadaver.

Når sådanne ekstremer er nået i fremstilingen af den døde Gud, er der ikke længere behov for at udtænke mere ekspressive iscenesættelser; man er beredt på skriget fra Zarathustra, hos Nietzsche. Scenens baggrund og dens aktører er allerede indlejret i den kollektive erindring, og man skal blot åbne øjnene en smule mere for billedets fakticitet, så forsvinder selve den trøst offeret indebærer, og mennesket er faderløst, ensomt og henvist til sig selv. 
Kristusfigurens rolle $\mathrm{i}$ den gradvise udvikling af idéen om Guds død er behandlet direkte i en fiktion af Jean Paul med titlen Traumdichtung, Rede des todten Christus vom Weltgebäude herab, daß kein Gott sei 1796. I denne fantasi der udgør et vigtigt forspil til Nietzsche, er det Kristus selv, der siger, at Gud er død og at vi alle er faderløse. Jeg vil anføre de mest slående påstande i dette drømmedigt, der ved udgivelsen vakte meget stor genklang $i$ Frankrig. På spørgsmålet fra de døde:

„Oh Kristus! Findes Gud ikke?" svarede han: - “Han eksisterer ikke ... Jeg har gennemvandret alle verdener, jeg har løftet mig op over alle sole, og heller ikke der findes Gud; jeg er steget ned til universets yderste grænse, jeg har skuet i afgrunden og råbt på Gud: Fader, hvor er du? Men jeg fik ikke andet svar end lyden af regndråberne, der dråbe for dråbe faldt $i$ afgrunden ... Vi er alle faderløse, I og jeg, vi har ingen Fader..."

Men Gud dør for at genopstå. Det siger dogmet, som maleriet efterlever og lovpriser, og som Grünewald heller ikke kan undsige sig. Hans Opstandelsen på altertavlen i Isenheim, på den yderste højre tavle i første udslåede tilstand, viser en blond, sund og tiltalende Kristus, der intet har til fælles med det tilsigtet frastødende kadaver overladt til forrådnelsens opløsning på det centrale billede (Korsfrestelsen) og på fodstykket (Gravlæggelsen), der ses når altertavlen er lukket. En umådeligt stor gul strålekrans omgiver denne Kristus, hans harmoniske krop og venligt forekommende ansigt, mens han mildt fremviser sine blodige sårmærker. Badet i dette gyldne lys forvandles Kristi krop til en aftensol. Lyset begynder at smelte, cirkel bliver til kurve, går over i purpur, inden det i en umærkelig skiften forandrer sig til en lysende blå, hvis tyrkise farvespil skiller sig ud fra himlen i baggrunden, der mørkner med den nedgående sol.

Hvilken overraskelse var det så ikke, da jeg - en sen eftermiddag i efteråret netop ved allehelgensdag, på vej ud af Colmar efter at have besøgt denne samling, i folkemunde kaldet Nordens Sixtinske Kapel - plụdselig stod over for den samme cirkel af lys, et himmeldiadem der kronede en kold og pragtfuld dag i Alsace, hvis gyldne farver kastedes tilbage på de bølgende vinmarker 
(der endnu ikke havde tabt deres gule blade) og på støvet der dansede i luften, for til sidst at samles i horisonten i kemisk ren form og forgylde hele synsfeltet, som en cirkel af energi hvis guldtunge brændpunkt gik over i purpur, derefter blånede og opløstes i en mørk azur, der indvarslede aftenens komme. Således blev det, der syntes at være et symbolsk lys skabt af maleren for med intensitet og klarhed at belyse Guds tilbagevenden til livet, den guddommelige genfødsel - alt dette blev nu åbenbaret for mig i sin sublime realitet af selve landskabet og årstiden. På århundreders afstand gjorde det mig til malerens samtidige, han der gennem sin kunst må have fastholdt dette samme syn, som nu udspillede sig for mine øjne, et øjebliks nåde vækkede mig midt i desillusioneringens og faderløshedens tidsalder, og lod mig erkende det guddommeliges evige spor. Malerens mesterskab har altså her blot bestået i, at han på sit underlag af lindetræ imiterede den epifani, der havde udspillet sig med naturen som baggrund. Ligesom han må have hentet inspirationen til sin fremstilling af Kristus som pestramt på lazaretterne blandt ofrene for meldrøjesyge, ${ }^{6}$ hvis behandling blev varetaget af Antoniusordenen, som også var dem, der havde bestilt altertavlen. For at lade det æstetiske komme til sin ret i det teologiske tableau (og findes der noget bedre billede på Forløsningen end denne dobbelte fremstilling af Kristus, der efter at have gennemgået de mest fysiske smerter forvandles til et lysende væsen) må maleren have udformet de to modstridende sekvenser på basis af virkelighedens modeller, ved at iagttage først den yderste menneskelige lidelse og dernæst naturens forunderligste lys, og foreningen af de to i ét værk skaber en intensitet, der, i det øjeblik hvor alle værkets komponenter udfylder bestillingens symbolske intention, forbliver kunstværkets privilegium.

Kristus, hvis korsfæstelse forbereder idéen om Guds død, dør for at genopstå, jeg har gentaget det og alle ved det. Gennem denne dualitet er han forbundet med Dionysosfiguren. Det er ikke tilfældigt, når disse to figurer nævnes i Hölderlins elegi Brød og vin, der er et vigtigt bidrag til formuleringen af den tanke vi nærmer os, med erkendelsen af at Guderne har vendt sig bort fra os, og med digterens vilje til at forblive på spændt udkig efter 
den Gud som skal komme, for i beruselsen i det mindste at erkende sporene efter det guddommelige: „Fordi han [vinguden] forbliver og selv bringer sporet af de flygtede guder / Ned til de gudløse i deres dystre formørkelse ". ${ }^{7}$

Endnu et argument, der legitimerer associationen mellem Kristus og Dionysos, fremgår ved et sideblik til islamisk teologi. Denne religions lærde var ikke uvidende om den Guds død, hvorom kristendommen former sig; de måtte forholde sig til tanken; men de kunne ikke se andet i den end vanvid, hvilket får én til at tænke på den oprindelige Dionysosfigur, der også er ekstasens og vanviddets gud. Hvordan man end anskuer det, iscenesættelserne af Guds død udgør en sammenhængende tradition såvel i oprindelse som i videreførelse, såvel hos tilhængere som hos dem der, indefra eller udefra, med reaktionært eller revolutionært sigte, smæder dogmet.

\section{VII}

For at fuldende min occidentaliseringsproces, for at bringe den occidentale metode over på min egen fødejord og for at føre kritikkens opgave til ende, måtte jeg tage min egen tro på ordet og underkaste den de samme spørgsmål. Derunder blev det klart for mig, at idéen om Guds død ikke ville kunne overføres til Islam. Den opfattes, som vi lige har set, på sit højeste som udtryk for en radikal vildfarelse. En sådan tanke om Guds død er i virkeligheden udelukket, for en tro der baserer sig på Koranens ord, fordi den ikke er forkyndt i dogmet.

Hvad siger egentlig det islamiske dogme, hvilket budskab formidler det, der, hvis man tog det bogstaveligt, ville kunne åbne et helt nyt og grænseoverskridende perspektiv, som vor tidsalders universalitet, dvs. verdens occidentalisering, kræver det? Man bør ikke glemme, at Islams profet kalder sig profeternes segl; med ham fuldendes monoteismen; han vil forblive den sidste, der har modtaget Loven. En sådan påstand er og bliver et dogme, uanset om det også hidtil er blevet bekræftet af historien, idet ingen religion, ifølge Islam, siden har kunnet hævde universel udbredelse. 
Ifølge dogmets ord afslutter og fuldender Islam altså en æra. Men i det øjeblik man forkynder en lukning, bebuder man samtidig en åbning, idet man taler om en slutning, vækker man tanken om en ny begyndelse. En æra er forseglet, en anden begynder. Det er den logiske tendens, der styrker os i den opfattelse, at vi efter den lange og smukke erfaring af Islam nu forlader monoteismen for at fortsætte i lyset af et andet princip. Dogmet selv rummer skjult muligheden for at forlade monoteismen, afslutte den.

I Islams åndelige historie hạr der været mindst to betydende forsøg på at realisere denne mulighed, i øvrigt, som samtiden krævede det, med fastholdelse af de væsentlige trosartikler. De to doktriner det drejer sig om, er forblevet inden for rammerne af Islam, selv om én har dannet grundlag for en skismatisk retning og den anden for en ambivalent teori, der med sin ligestilling af uforenelige modsætninger har nærmet sig grænsen til kætteri. Det drejer sig på den ene side om imamatets afløsning af profeterne inden for shiismen; og på den anden side om sufismens distinktion mellem profet og hellighed: Jeg skal ikke fortabe mig i de nærmere detaljer i disse meget komplekse doktriner, der er blevet indgående studeret af Henry Corbin og Michel Chodkiewicz: her er ærindet generelt inden for en digteriske erfaring at skitsere nogle holdepunkter for en mulig kritik. Og det er værd at erindre sig, at de omtalte doktriner havde som mål at frisætte den kreative og åndelige energi, der risikerede at blive kvalt under det profetiske segls autoritet. Dermed var de ganske enkelt udtryk for en fordring fra livet selv.

Med disse to snedige interne strategier i fortryllelsens og troens tidsalder, blev det muligt at lade bogstavet befrugte af fortolkning, at presse kernen og forvandle den til olie. Den nyvundne nærhed til det guddommelige tillod visse helgener, i særdeleshed Ibn Arabi (1165-1240), at kappes med og sågar overgå profeterne med hensyn til dybden af deres erfaringer. Det eneste, som disse hellige indrømmede overskred deres kompetence, var indstiftelsen af Loven. Århundreder senere skulle dogmet blive rystet af revolutioner, hvis oprindelse var at finde et andet sted, nærmere bestemt i Europa. De to omtalte forsøg der- 
imod ville blot tage den værste brod af dogmet for derefter at kunne anpasse sig det; og det i en sådan grad at de, i en mimning af forbilledet, begyndte at se forestillingen om lukning og fuldbyrdelse i deres eget perspektiv, idet de tilpassede begrebet om forsegling deres egne figurer, imamerne og wali'erne, de hellige. Men man forsøgte dog $\mathrm{i}$ begge tilfælde ud fra tanken om parusi at modstå den fristelse til forsegling, der uundgåeligt dukker op i enhver traditionel kultur.

Som afslutning vil jeg citere et berømt vers fra Koranen, fra suraen om tordenen (XIII, 38): "Hver tidsalder sin bog".8 I kommentarerne har man normalt undladt at forklare dette vers, der ikke engang kan reddes af sin kontekst, idet denne i lige så høj grad handler om åbenbarede budskabers midlertidige og tidsbundne karakter, - mens den sande Bog, der er hos Gud, aldrig vil blive overgivet i menneskers varetægt, den vedbliver at være uopnåelig for mennesker; det guddommelige bogstav der er i omløb blandt dem, er kun en kopi, en aktualisering af arketypen; og et aktualiseret bogstav rummer risikoen for at blive forældet: og efter endt brug venter tilintetgørelsen. I det følgende vers siges det: "Gud udvisker, hvad han vil, eller lader det bestä, hos ham er bogens Moder" (XIII, 39).9 - Endnu et argument, og denne gang oven i købet fra Skriften selv, der leder frem mod faderløsheden; mennesket rådes dog til at besinde sig på de evige ords forgængelighed, for så efter at have gennemlevet denne sorg at kunne engagere sig i nye opdagelsesfærder, hvis karakter af indvielse og ny begyndelse frisætter ukendte energier og indgiver mod til at udsætte sig for faren for at bukke under og dø. Men falder en sådan heroisme i tidens smag?

\section{Oversat af Cecilia Holmquist}




\section{Noter}

1. Jeg tilslutter mig her en ide fremført mundtligt af Fethi Benslama som indlæg på Carrefour européen des littératures i Strasbourg november 1992.

2. Les dits de Bistami, Paris, Fayard, 1989.

3. Jvf. Emile Benveniste Problèmes de linguistique générale, Paris, 1981.

4. Jvf. studier af Van Ess om dette problem.

5. Jvf. Rudolf Sellheim Die Madonna mit der Schahada, 1968.

6. "Le mal des ardents". Meldrøjesyge el. ergotisme, dødelig epidemi i Middelalderen, forårsaget af indtagelse af korn angrebet af meldrøjesvamp. Symptomerne var bl. a. ulægelige sårdannelser og koldbrand. Min note, $\mathrm{CH}$.

7. Oversættelse af Per Aage Brandt. $\mathrm{CH}$.

8. "Og det tilkom ikke noget sendebud at bringe et tegn, undtagen med Allahs billigelse. For enhver plan er der en (bestemt) frist". Det tilsvarende citat i A. S. Madsens danske oversættelse fra 1967. CH.

9. "Allah udsletter, hvad Han vil, og befæster, hvad Han vil. Og hos ham er kilden til (alle) befalinger". Ibid. $\mathrm{CH}$. 


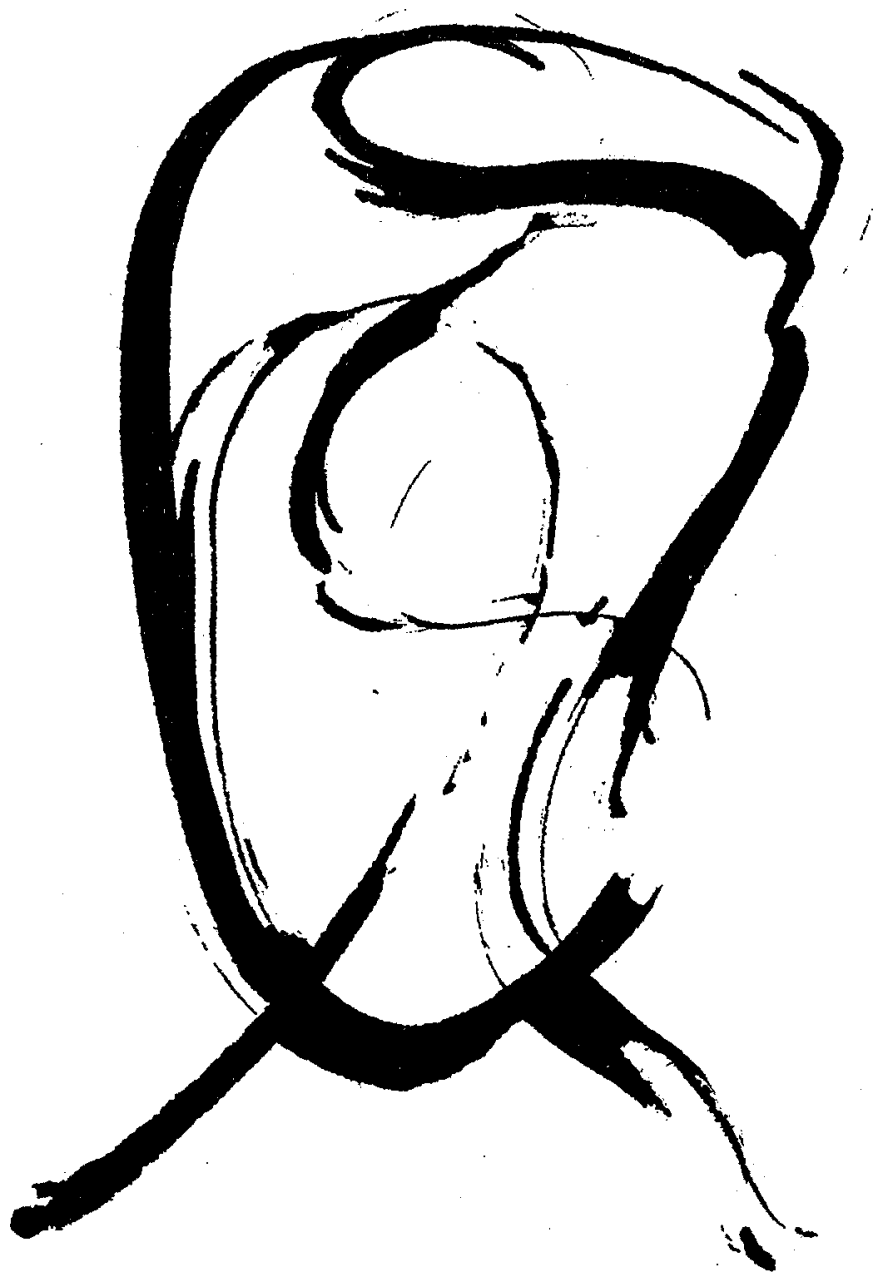

